\title{
CORRELATION BETWEEN BIOFILM FORMATION OF UROPATHOGENIC ESCHERICHIA COLI AND ITS ANTIBIOTIC RESISTANCE PATTERN.
}

Dr. SarojGolia, Dr. Vivek Hittinahalli, Dr. Sujatha K Karjigi, Dr. K. Mallika Reddy.

1. Professor \& HOD, Department of Microbiology, Dr. B.R. Ambedkar Medical College.

2. Associate Professor, Department of Microbiology, Dr. B.R. Ambedkar Medical College.

3. Post Graduate, Department of Microbiology, Dr. B.R. Ambedkar Medical College.

4. Post Graduate, Department of Microbiology, Dr. B.R. Ambedkar Medical College.

\section{CORRESPONDING AUTHOR:}

Dr. Vivek Hittinahalli,

Dr B R Ambedkar Medical College,

Kadugondanhalli, Bangalore-45,

Email id-vivekhitt@yahoo.com,

Ph- 009107760984581.

\section{ABSTRACT}

BACKGROUND: Microorganisms growing in multilayered cell clusters embedded in a matrix of extracellular polysaccharide (slime) which facilitates the adherence of these microorganisms to biomedical surfaces and protect them from host immune system and antimicrobial therapy. There are various methods to detect biofilm production like Tissue Culture Plate (TCP) ,Tube method (TM) ,Modified Congo Red Agar Method (MCRA),bio luminescent assay, piezoelectric sensors and fluorescent microscopic examination.

OBJECTIVES : This study was conducted to compare three methods for the detection of biofilms and compare with antibiotic sensitivity pattern, in uropathogenic Escherichia coli.

METHOD: This study was carried out at the Department of Microbiology Dr. B. R. Ambedkar Medical College from Dec 2011 to June 2012. Total number of 107 clinical Escherichia coli isolates were randomly selected from all age groups were subjected to biofilm detection methods and their antibiotic resistance pattern was compared. Isolates were identified by standard phenotypic methods. Biofilm detection was tested by TCP, TM and MCRA methods .

Antibiotic susceptibility test of uropathogenic E coli was performed using Kirby -Bauer disc diffusion method according to CLSI guidelines.

RESULTS: From the total of 107 clinical isolate 74 (69.1\%) isolates showed biofilm formation by all the TCP, TM, CRP methods. Biofilm forming isolates from catheter associated UTI showed drug resistance to more than 6 drugs. Only 2(13.3\%) isolates from Asymptomatic UTI showed biofilm by TM \& MCRA methods \& were sensitive all drugs. Biofilm forming isolates from symptomatic UTI showed mixed drug resistance pattern.

CONCLUSION: We conclude from our study that biofilm formation is more common in catheterized patients. TCP method is more quantitative and reliable method for the detection of biofilm forming micro-organisms as compared to TM and MCRA methods. So TCP method can be recommended for screening of biofilm as virulence marker in drug resistant $\mathrm{E}$ coli isolates. KEY WORDS: Escherichia coli, Biofilm, Drug Resistance, Congo Red Agar, Tissue Culture Plate 
INTRODUCTION: E coli accounts for 70 to $95 \%$ of urinary tract infections ${ }^{1,13}$

Bacteria follow ascending route of infections in $90 \%$ of urinary tract infections.

These are primarily derived from fecal flora of the host, but haematogenic infections do occur.

Virulence factors like adhesins, toxins, lipo polysaccharides, iron acquisition, presence of capsule, or serum resistance, determine the uropathogenicity of E.coli strains.

Adhesion to epithelial cells of urogenital bacteria is generally accepted as being essential for Uropathogenic bacteria because otherwise the bacteria would be washed out rapidly.

In $100 \%$ E.coli isolates from pyelonephritis patients \& 17\% E.coli isolates from Asymptomatic bacteriuria, pap (pili associated pyelonephritis ) was a significant virulence factor.

Uropathogenic E.coli (UPEC) can also express a fimbrial adhensins like AFA I, AFA III , which are encoded by gene clusters.

UPEC can invade and colonise the bladder epithelium establishing a urinary tract reservoir allowing an explanation of recurrent UTI that does not necessarily involve reinfection via the Gastrointestinal tract 1,10

Biofilm is an aggregate of micro-organism in which the cells are irreversibly attached to substratum or to each other.

They are embedded in a matrix of extra cellular polymeric substances (EPS) in which they have produced and exhibit an altered phonotype with respect to growth rate and gene transcription 2,3

Availability of key nutrients, chemotaxis towards surface, motility of bacteria, surface adhesins and presence of surface bacteria are some factors which influences biofilm formation ${ }^{4}$ The bacteria enclosed within the biofilm are extremely resistant to treatment. This may be because the drug concentration obtained may be insufficient in certain areas of the film.

The bacteria located at the base of the biofilm are metabolically inactive and are thus resistant to certain antibiotics and possess active antibiotic degradation mechanism that contribute to avoid the accumulation of an effective drug concentration. ${ }^{19}$

So in this study we screened 107 non Repetitive Clinical urinary Isolates of E.coli received in Department of Microbiology Dr. B.R. Ambedkar Medical college by conventional microbiological methods\& were subjected to various methods of detections of biofilm production .These include Tissue Culture Plate (TCP)method,5 Tube method(TM) ${ }^{6}$, Modified Congo Red Agar method(MCRA) ${ }^{7}$.

The samples received by patients were also divided into three groups namely catheter associated infection, Asymptomatic bacteriuria and Symptomatic bacteriuria.

The antibiotic susceptibility test was carried out by Kirby Bauer Disc diffusion Technique on Mueller Hinton agar.

OBJECTIVE: Evaluation of different detection methods of biofilm formation of uropathogenic E.coli and their drug susceptibility pattern.

MATERIALS AND METHODS:

PLACE AND DURATION OF THE STUDY: The prospective study was conducted at the Department of Microbiology, Dr. B.R. Ambedkar Medical College from Dec 2011 to June 2012.

INCLUSION CRITERIA: Pure growth of Escherichia coli isolates were randomly selected from all age groups.

Journal of Evolution of Medical and Dental Sciences/Volume1/ Issue3/July-Sept 2012 Page 167 
E coli isolated from significant bacteriuria, in urine samples of catheterized patients, antenatal cases ,UTI complicated by urinary obstruction, antibiotic therapy, recurrent infections, chronic prostatitis were selected.

EXCLUSION CRITERIA; Insignificant bacteriuria, mixed growth \& any other organism showing significant growth .

SELECTION OF THE ISOLATES : Total number of 107 urine E coli isolates were subjected to biofilms detection methods. The urine samples of patients were divided into three groups namely - Catheter associated infections, Symptomatic bacteriuria, and Asymptomatic bacteriuria.

The organisms were identified by conventional microbiological methods.

The antibiotic susceptibility test was carried out by Kirby Bauer Disc diffusion method using reference strain of positive biofilm producer E.coli ATCC-25922.

Statistical method used was linear correlation.

\section{TISSUE CULTURE PLATE METHOD5,8:}

The organisms isolated from fresh agar plates were inoculated in Brain Heart Infusion(BHI) with $2 \%$ sucrose incubated for $24 \mathrm{hrs}$ at $37^{\circ} \mathrm{c}$ in stationary conditions. Broth was diluted 1:100 with fresh medium. Individual wells of sterile polystyrene 96 well flat bottom culture plate well were filled with $200 \mathrm{ul}$ aliquots of diluted cultures. Only medium served as control to check sterility and nonspecific binding of media. ${ }^{9}$

The TCP were incubated for $24 \mathrm{hrs}$ at $37^{\circ} \mathrm{c}$. After incubation contents of each well was gently removed by taping the plates. The wells were washed four times with $0.2 \mathrm{ml}$ of phosphate buffer saline (PBS pH 7.2) to remove free floating planktonic bacteria. Biofilms formed by adherent 'sessile' organisms in plate were fixed with sodium acetate $(2 \%)$ and stained with crystal violet $(0.1 \% \mathrm{w} / \mathrm{v})$ for one minute. Excess stain was rinsed off by thorough washing with deionized water and plates were kept for drying. Adherent E.coli cells usually formed biofilm on all side wells and were uniformly stained with crystal violet. Optical Density (OD) of stained adherent bacteria was determined with a micro ELISA auto reader (model 680, Bio rad) at wavelength of $570 \mathrm{~nm}\left(\mathrm{OD}_{570 \mathrm{~nm})}\right.$. These OD values were considered as index of bacteria adhering to surface and forming biofilms. ${ }^{8}$

Experiment was performed in triplicate and repeated three times, the data was then averaged and standard deviation was calculated. To compensate for background absorbance, OD readings from sterile medium, fixation and dye were averaged and subtracted from all test values. The mean OD value obtained from media control well was deducted from all test values. Classification of Bacteria Adherence:

We classified based on OD values obtained for individual strains of E.coli, but moderate biofilm forming isolates are taken as biofilm forming isolates.

\begin{tabular}{|l|l|l|}
\hline Mean OD value & Adherence & $\begin{array}{l}\text { Biofilm } \\
\text { formation }\end{array}$ \\
\hline$<0.120$ & Non & Non/weak \\
\hline $0.120-0.240$ & Moderate & Moderate \\
\hline 0.240 & Strong & High \\
\hline
\end{tabular}

Journal of Evolution of Medical and Dental Sciences/Volume1/ Issue3/July-Sept 2012 Page 168 
Table no 1; Detection of biofilm formation by mean OD values

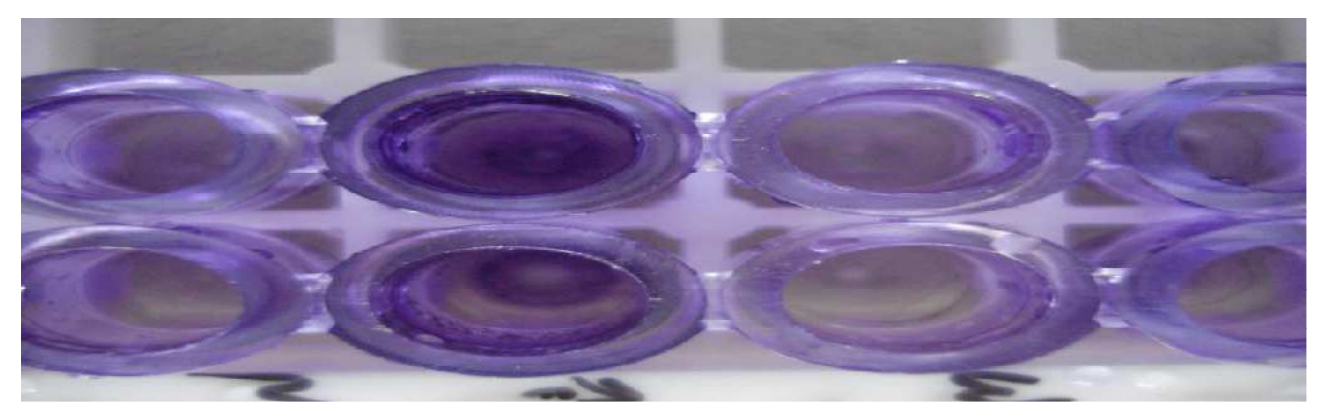

Negative

OD $<0.120$
Strong positive

OD $>0.240$

Fig 1 Detection of biofilm formation by mean OD values.

TUBE METHOD : A quantitative assessment of biofilm formation was determined as previously described by Christensen et al BHI with2\% sucrose was inoculated with loopful of microorganisms from overnight culture plates incubated for $24 \mathrm{hrs}$ at $37 \mathrm{c}$. Tubes were decanted and washed with PBS and dried tubes were stained with crystal violet $0.1 \%$. Excess stain was removed and tubes were washed with deionized water Tubes were then dried inverted position and observed for biofilm formation.

Biofilm formation was considered positive when visible film lined the wall and bottom of the tube ring formation at the liquid interface was not indicative of biofilm formation, and interpreted as positive (tube 1) as negative(tube2). Experiments were performed in triplicate and repeated three times ${ }^{8}$ but moderate biofilm forming isolates are taken as biofilm forming isolates

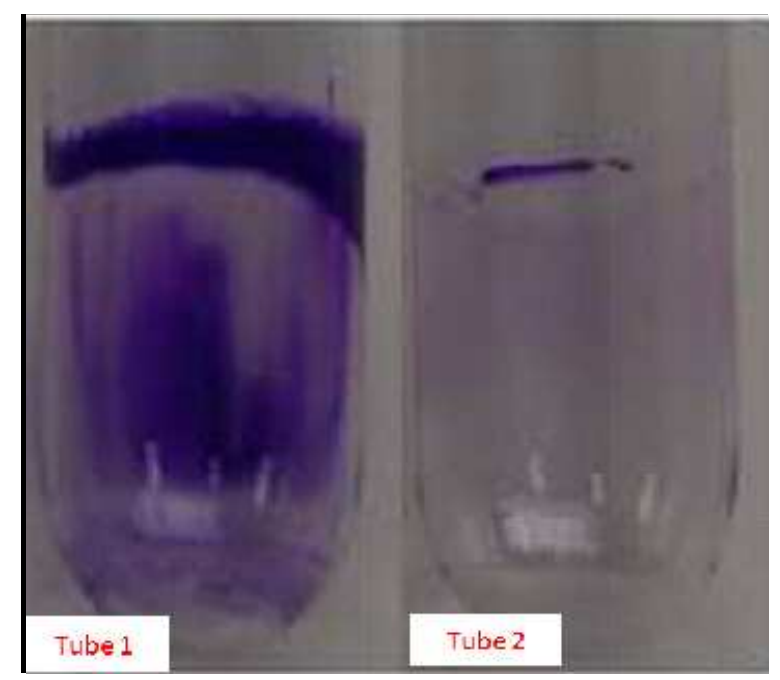

Figure 2 . Tube 1 showing strong biofilm formation. Tube 2 negative for biofilm production.

Journal of Evolution of Medical and Dental Sciences/Volume1/ Issue3/July-Sept 2012 Page 169 
MODIFIED CONGO RED AGAR METHOD (CRA): Freeman et al ${ }^{15}$ had described an alternative method of screening biofilm formation by E coli isolates. In this study we use modified Congo red agar for biofilm formation. In vitro slime production ability on the published Congo red agar by Freeman et al (1989) in diffuse black pigment in the agar with growth of black pigmented colonies but pigmentation decreased with time. In the present study the modified Congo red agar (MCRA) was optimized to get strong black pigmentation at $48 \mathrm{hrs}$ incubation and then for 2-4 days room temperature. Black colored colonies with dry crystalline consistency interpretedas positive biofilm producing strains. Red coloured colonies- interpreted as negative for biofilm production

\begin{tabular}{|l|l|l|}
\hline Composition /Litter & Congo Red Agar & Modified Congo red agar \\
\hline Congo red & $0.8 \mathrm{~g}$ & $0.4 \mathrm{~g}$ \\
\hline Sucrose & $36 \mathrm{~g}$ & - \\
\hline Glucose & - & $10 \mathrm{~g}$ \\
\hline BHAI & $52 \mathrm{~g}$ & - \\
\hline BAB-2 & - & $40 \mathrm{~g}$ \\
\hline Water & $100 \mathrm{ml}$ & $1000 \mathrm{ml}$ \\
\hline
\end{tabular}

Table 2; composition of Congo red agar.

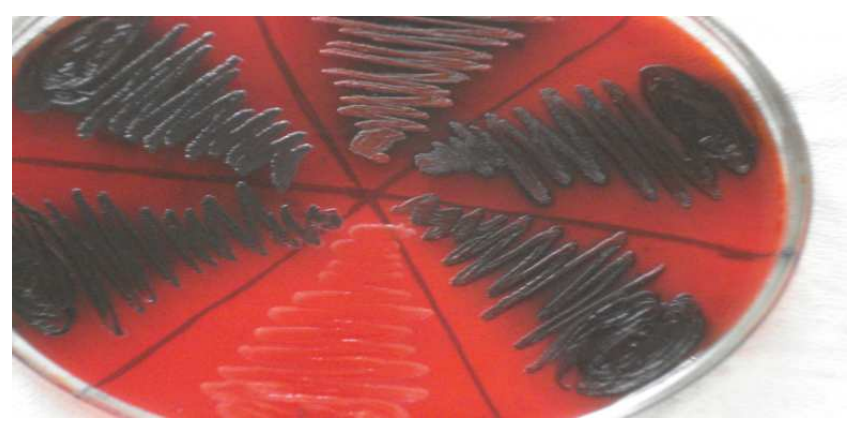

fig 3 Congo red agar plate showing biofilm formation a) dry crystalline colonies-positive for biofilm, b)red colored colonies-negative for biofilm

Antibiotic susceptibility test of biofilm producing bacteria was done on Mueller Hinton agar using the following antibiotic discs ${ }^{12}$ :

Norfloxacin, Nitrofurantoin, Ceftizoxime,ceftazidime, Amoxyclavulanic acid, Cotrimoxazole, Ampicillin ,Amikacin

Imipenem,Tetracycline.

All the antibiotic disc were obtained from the Himedia. E coli ATCC 25922 were used as positive control and susceptibility testing was performed by using the Kirby Bauer Disc Diffusion Technique according CLSI guidelines.

RESULTS: Among 107 patients 65 were males and 42 were females. From the total of 107 clinical isolates 74( $69.1 \%$ ) isolates showed biofilm formation by all the TCP,TM,CRP methods. Among 67 catheter associated UTI ,60 (89.5\%)isolates produced biofilm by all the three methods .

Journal of Evolution of Medical and Dental Sciences/Volume1/ Issue3/July-Sept 2012 Page 170 
Among Asymptomatic bacteriuria out of 15 isolates none produced biofilm by TCP method. 2(13.3\%) produced biofilm\&13(86.6\%) were non biofilm producer by TM \&MCRA method .

Among symptomatic UTI complicated from urinary obstructions, antibiotic therapy, recurrent infections, chronic site of infections(chronic prostatitis or stones), 14(56\%) were biofilm producers by TCPmethod,12(48\%) by TM method,18(72\%) by MCRA method, as shown in table3 \& chart 3.

\begin{tabular}{|l|l|l|l|l|l|l|}
\hline \multirow{2}{*}{$\begin{array}{l}\text { E coli isolated } \\
\text { from }\end{array}$} & \multicolumn{2}{|l|}{ TCP } & & NM & \multicolumn{2}{l|}{ MCRP } \\
\cline { 2 - 7 } & nonbiofilm & Biofilm & & biofilm & Nonbiofm \\
\hline $\begin{array}{l}\text { Catheter } \\
\text { associated } \\
\text { infection } \\
\text { (n=67) }\end{array}$ & $60(89.5 \%)$ & $7(10.44 \%)$ & $60(89.5 \%)$ & $7(10.44 \%)$ & $60(89.5 \%)$ & $7(10.44 \%)$ \\
\hline $\begin{array}{l}\text { Asymptomatic } \\
\text { bacteriuria } \\
\text { (n=15) }\end{array}$ & 0 & 15 & $2(13.3 \%)$ & $13(86.6 \%)$ & $2(13.3 \%)$ & $13(86.6 \%)$ \\
\hline $\begin{array}{l}\text { Symptomatic } \\
\text { bacteriuria } \\
\text { (n=25) }\end{array}$ & $14(56 \%)$ & $11(44 \%)$ & $12(48 \% 0$ & $13(52 \%)$ & $18(72 \%)$ & $7(28 \%)$ \\
\hline
\end{tabular}

Table no 3 Above table shows percentage of biofilm \& non biofilm forming E.coli isolates \&its correlation with patient's condition.

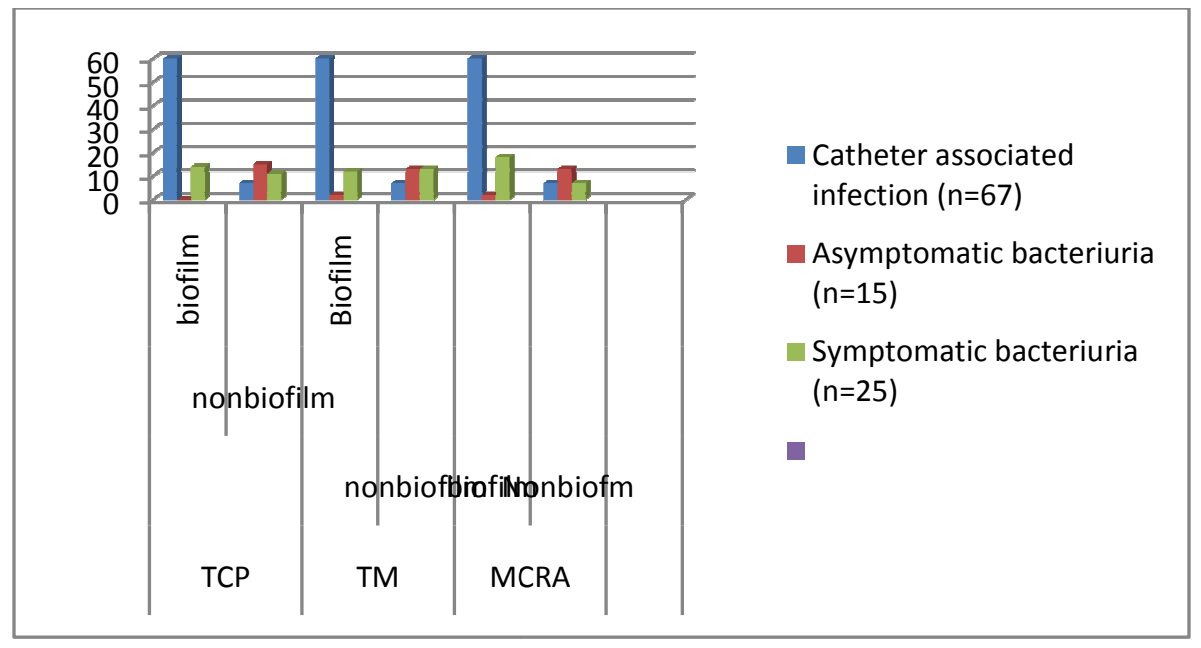

CHART NO 1 : ABOVE CHART SHOWS PERCENTAGE OF BIOFILM \& NON BIOFILM FORMING E.COLI ISOLATES \& ITS CORRELATION WITH PATIENT'S CONDITION. 
Table 4 \& chart 4 shows resistance percentage of each antibiotic. These biofilm producing isolates were compared with drug resistance pattern as shown table $5 \&$ chart 3 . Out of 74 biofilm producing isolates 60 were catheter associated UTI \&14 were from symptomatic UTI. 70( $94.5 \%$ ) by TCP, 68( $91.5 \%$ ) by TM method,\& 71(87.6\%) by MCRA method showed drug resistance to more than 6 drugs. $E$ coli isolates from asymptomatic UTI showed sensitive to all drugs. Isolates from symptomatic UTI showed mixed drug resistance pattern.

\begin{tabular}{|l|l|}
\hline Antibiotic used & $\begin{array}{l}\text { Number of isolates showed } \\
\text { resistant's } \mathbf{( \% )} \mathbf{n}=\mathbf{1 0 7}\end{array}$ \\
\hline Ampicillin(amp) & $90(84 \%)$ \\
\hline Cotrimoxozole & $82(76.6 \%)$ \\
\hline Amoxyclav & $75(70 \%)$ \\
\hline Amikacin & $58(54.2 \%)$ \\
\hline Ceftizoxime & $74(69.1 \%)$ \\
\hline Ceftazidme & $79(73.8 \%)$ \\
\hline Norflox & $81(75.7 \%)$ \\
\hline Nitrofurantoin & $78(72.9 \%)$ \\
\hline Tetracycline & $74(69.8 \%)$ \\
\hline Imipenem & $30(28.3 \%)$ \\
\hline
\end{tabular}

Table -4 Resistance percentage of each antibiotic drug to E coli isolates

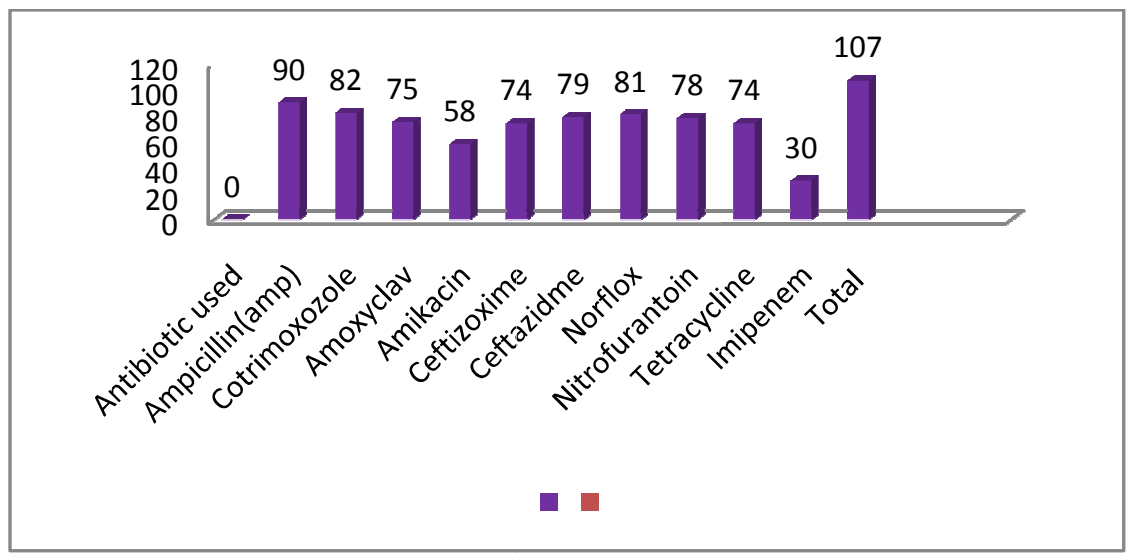

Chart 2 Resistance percentage of each antibiotic drug to $\mathrm{E}$ coli isolates.

\begin{tabular}{|l|l|l|l|}
\hline & TCP & TM & CRM \\
\hline $\begin{array}{l}\text { Resistance to more } \\
\text { than 6 drugs }\end{array}$ & $70(94.5 \%)$ & $68(91.8 \%)$ & $71(87.6 \%)$ \\
\hline $\begin{array}{l}\text { Resistance to 5 to 6 } \\
\text { drugs }\end{array}$ & $4(5.4 \%)$ & $6(8.1 \%)$ & $6(7.4 \%)$ \\
\hline Sensitive to all & 0 & 0 & $3(4.9 \%)$ \\
\hline Total & 74 & 74 & 80 \\
\hline
\end{tabular}

Table 5 The above table shows the relation between biofilm formation and antimicrobial resistance pattern.

Journal of Evolution of Medical and Dental Sciences/Volume1/ Issue3/July-Sept 2012 Page 172 


\section{ORIGINAL ARTICLE}

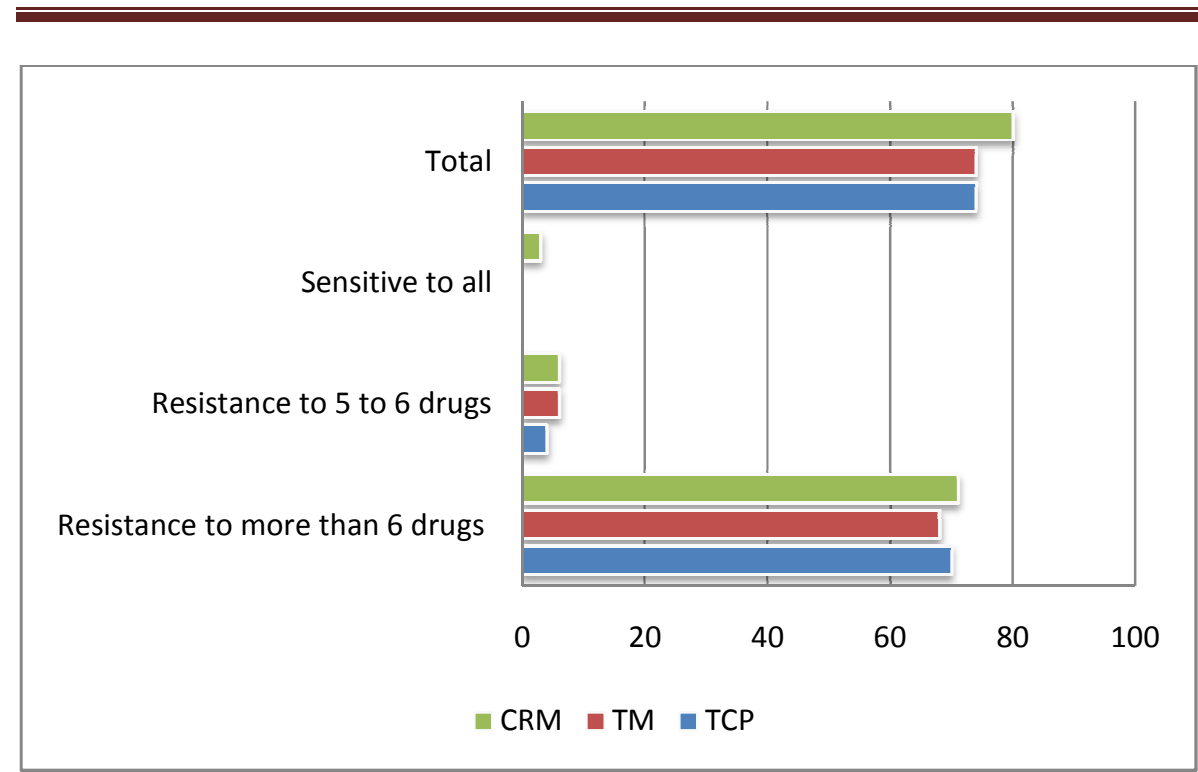

Chart 3The relation between biofilm formation and antimicrobial resistance pattern

\begin{tabular}{|l|l|l|l|}
\hline Antibiotics & $\begin{array}{l}\text { Catheter } \\
\text { associated } \\
\text { infection } \\
\mathrm{N}=60\end{array}$ & $\begin{array}{l}\text { Symptomatic } \\
\text { bacteriuria }\end{array}$ & $\begin{array}{l}\text { Non biofilm } \\
\text { Forming } \\
\text { Isolates } \\
\mathrm{N}=33 .\end{array}$ \\
\hline Ampicillin(amp) & 60 & 14 & 16 \\
\hline Cotrimoxozole & 60 & 14 & 8 \\
\hline Amoxyclav & 58 & 12 & 5 \\
\hline Amikacin & 50 & 8 & 0 \\
\hline Ceftizoxime & 60 & 14 & 0 \\
\hline Ceftazidme & 60 & 14 & 5 \\
\hline Norflox & 60 & 14 & 7 \\
\hline Nitrofurantoin & 60 & 14 & 4 \\
\hline Tetracycline & 60 & 14 & 0 \\
\hline Imipenem & 24 & 6 & 0 \\
\hline
\end{tabular}

Table 5 The above table shows correlation between antibiotic resistance pattern with patient's condition $\&$ biofilm formation. ( $\mathrm{N}=$ number of biofilm positive isolates).

Chart 4 The above chart shows correlation between patient's condition ,biofilm formation $\&$ antibiotic resistance pattern. $N=$ number of biofilm positive isolates.

DISCUSSION: Bacterial adhesion has long been considered as virulence factor contributing to infection associated with catheter and other including medical devices. ${ }^{13}$

There are two possible explanations for the ability of $E$ coli species to colonies artificial materials. The first and the bacterial production of polysaccharide slime, the second one is the presence of adhesins for the host matrix proteins that are absorbed on to the biomedical surface 15

There are various methods for biofilm detection ${ }^{5,6,7}$. 
In this study we evaluated 107 isolates from urine samples by three screening methods for their ability to form biofilms .

In our study we found that the majority of biofilm producing bacteria was form catheterised patients (89.5\%) similarly, Donlan 2,3 reported in his study the association of biofilm producing bacteria with urinary catheters.

In our study we performed TCP and TM by addition of $2 \%$ sucrose to BHI broth. Sugar supplementations is essential for biofilm formation ${ }^{8}$.This was reported by studies conducted by Mathur T et all.

In modified TCP method extended incubation for $24 \mathrm{hrs}$ could lead to a better discrimination between moderate and non- biofilm producing isolates ${ }^{17}$. This was also observed in our study.

Biofilm exhibits more resistance to broad Spectrum antibiotics ${ }^{20}$. This supports that biofilm adds to the virulence profile of microorganism's biofilm production. 16

The Tube method correlates well with TCP test for strong biofilm production but it was difficult to discriminate between weak and biofilm negative isolates due to the variability is observed results by different observers so in agreement with previous report Tube test cannot be recommended as a general screening test to identify biofilm producing isolates. ${ }^{18}$

CONCLUSION: By this study we conclude that biofilm forming microorganisms show resistance to many drugs. TM method showed 74 isolates as biofilm formers ,TCP method also showed 74 isolates as biofilm formers but MRCA showed 80 isolates as biofilm formers .Only 74 isolates that showed biofilm formation correlated with patients condition and antibiotic resistance pattern, by this 6 isolates were false positive by MRCA method .TCP and TM method are more reliable for detection of biofilm formation, when correlated with patient's clinical condition and drug resistance pattern of biofilm forming isolates TM method is more subjective ,differs with different observers, so TCP method is more reliable and accurate among all, as CRA method showed false positive. Our study concludes TCP method is better method for screening of biofilm formation as virulence marker in drug resistant $\mathrm{E}$ coli isolates.

\section{REFERENCES:}

\section{Book.}

1)Topley And Wilsos $10^{\text {th }}$ edition, bact vol 2;p1379-1380.

\section{Journals.}

2)Donlan RM(2001).Biofilms and device associated infections.Emerg.infect Dis 7:277-281.

3)DonlanRM,costerton w.Biofilms:survival mechanisms of clinically relevant Microorganisms,clin Microbiol Rev 2002;15(2);167-93.

4)Thomas D,Day F.Biofilmformation by plant associated bacteria.Ann Rev Microbiol2007;61:401-22.

5)Christensen GD,simpsonWA Younger JAet al.Adherance of coagulase negative staphylococci to plastic tissue cultures ; a qualitative model for the adherence of staphylococci to medical devices J Clin Microbiol 1995;22:996 -1006.

6) Christensen GD,simpsonWA.Bisno AL, BeacheyEH Adherance of slime producing strains of staphylococcus epidermidis to smooth surfaces.InfectImmune 1982;37:318 -26.

7) Freeman DJ, Falkiner FR and Keane CT (1989). New method for detecting slime production by coagulase negative staphylococci. Journal of Clinical Pathology., 42 (8): 872-874.

8)T Mathure et al ijmm aug 19 2011, ip;27.7.49.6

Journal of Evolution of Medical and Dental Sciences/Volume1/ Issue3/July-Sept 2012 Page 174 
9)Quantification of biofilm in microtiter plates: Overview of testing conditions and practical recommendations for assessment of biofilm production by staphylococci Stepanović, S., Vuković, D., Hola, V., Bonaventura, G.D., Djukić, S., Ćirković, I., Ruzicka, F.APMIS. 2007; 115(8): 891-899[Pubmed]

10) Stickler DJ (2005) Urinary catheters: ideal sites for the development of biofilm communities. 11)Stickler DJ, Young R, Jones G, Sabubba NA, and Morris NS (2003) Why are Foley catheters so vulnerable to www.sgm.ac.uk/pubs/micro_today/pdf/020505.pdf. Microbiology Today, Feb: 22-25..

12) Makie \& McCartney practical medical microbiology, 14th ed., Churchill Livingstone In., New York 131-149.

13)Madbhusharma, Aparna,Sarita, DOI:10.4103/0377-4929,48960.

14) Montanaro L, Arciola CR, Borsetti E, Brigotti M, and Baldassarri L (1998) A polymerase chain reaction (PCR) method for the identification of collagen adhesin gene (cna) in Staphylococcus-induced prosthesis infections. New Microbiol 21: 359-363.

15)Montanaro L, Arciola CR, Borsetti E, Brigotti M, and Baldassarri L (1998) A polymerase chain reaction (PCR) method for the identification of collagen adhesin gene (cna) in Staphylococcusinduced prosthesis infections. New Microbiol 21: 359-363.

16) Salwa S. Seif El-Din et al Journal of American Science, 2011;7(1)

17) Ludwicka A, Switalski LM, Lundin A, Pulverer G, Wadstrom T. Bioluminescent assays for measurement of bacterial attachment to polyethylene. J Microbiol Methods1985;4:169-77

18) Christensen GD, Simpson WA, Bisno AL, Beachey EH. Adherence of slime-producing strains of Staphylococcus epidermidis to smooth surfaces. Infect Immun1982;37:318-26

19)Anderson GG.Palermo JJ,Roth R,Heuser J, Hultgren SJ.Intracellular bacterial Biofilm- like pods in urinary tract infection.science 2003;301:105-7.

20)Suman E,J Jose,S Varghese,MS Kotian aug 19 2011,IP;27.7.49.6

Journal of Evolution of Medical and Dental Sciences/Volume1/ Issue3/July-Sept 2012 Page 175 